\title{
Characterization of unburned carbon separated from power plant slag
}

\author{
K. Wierzchowski ${ }^{1}$ B. Białecka ${ }^{1} \cdot$ J. Calus Moszko' ${ }^{1} \cdot$ A. Klupa $^{1}$
}

Received: 8 January 2019 / Revised: 9 January 2020 / Accepted: 26 January 2020 / Published online: 1 February 2020

(c) The Author(s) 2020

\begin{abstract}
This article presents the results of slag property studies, for characterization of unburned carbon separated. Size composition and loss-on-ignition distribution as a function of particle size were studied. The density analyses were performed for the selected size fractions. The successful tests on carbon particle separation using: the magnetic separation, separation in heavy liquids with magnetic separation of light ends and separation in a rising water stream with magnetic separation of the overflow methods, were performed. At laboratory scale and with using similarly rising water stream with magnetic separation methods, concentrates with 71-85\% loss-on-ignition were obtained. Using gravitational separation method and magnetic separation, concentrates with $57-86.5 \%$ loss-on-ignition were obtained.
\end{abstract}

Keywords Unburned carbon $\cdot$ Slag $\cdot$ Magnetic separation $\cdot$ Gravity separation

\section{Introduction}

The side effect of fossil fuel combustion in power plants is the high amounts of combustion waste, known as coal combustion by-products (CCB). In many countries, searches are underway for various effective ways of the recovery of coal combustion by-products (CCP), such as fly ash, bottom ash, boiler slag, gypsum from desulfurization, and fluidized bed combustion spent bed material (Anghelescu et al. 2017a). A total of 21.9 million tons of power industrial waste was generated in 2015 in Poland (GUS 2016). Most of the waste from the power industry consists of ash and slag mixtures originating from the wet disposal of combustion waste, constituting 12.0 million tons. The great majority of ash and slag mixtures is kept in storage, while only 0.1 million tons are subjected to recycling processes (GUS 2016). Ash and slag mixtures are most often utilized as construction materials for terrain levelling as well as for road foundations and highway embankments (Groppo 2011; Jayaranjan et al. 2014). There are also cases where selected components, separated from ash and slag mixtures, are used as aggregates in civil

Editorial responsibility: M. Abbaspour.

\section{J. Calus Moszko}

jmoszko@gig.eu

1 Główny Instytut Górnictwa, Central Mining Institute (GIG), Plac Gwarków 1, 40-166 Katowice, Poland engineering and as pozzolans for cement production (Cheriaf et al. 1999; Jayaranjan et al. 2014). Each use of CCB for industrial purposes must be preceded by precise studies of their physical and chemical properties, their suitability for the given purpose and their potential influence on the broadly understood natural environment. One of the factors limiting the industrial utilization of ash and slag mixtures is unburned carbon residues (EN 197-1:2011; Argiz et al. 2017). On average, the residual coal content of the ash is $3-5 \%$, which at current consumption represents millions of tons of unburned coal per year worldwide, which is easy to compare with the annual production level of a carbonate pool (Bartoňová 2015; Anghelescu et al. 2017b). A number of methods are known for the separation of unburned carbon from CCB. The electrostatic separation method of unburned carbon from specifically prepared fly ash has the greatest practical significance (Bittner et al. 2010; Ban et al. 1997; Soong et al. 2002; Baltrus et al. 2002; Koca and Koca 2009). Work conducted thus far concerning the separation of unburned carbon from slag or ash and slag mixtures have not yet found a practical application (Gray et al. 2002; Sahbaz et al. 2008; Kruger 2010; Ucurum et al. 2011).

Characteristics of the size composition were done, and the content of unburned coal in the separated size fractions was determined. The aim of this article was to analyse the possibility of separating unburned carbon particles from slag, and the following separation methods were used for the realization of this purpose: 
- magnetic separation,

- separation in heavy liquids and magnetic separation of light ends,

- separation in a rising water stream and magnetic separation of the overflow.

It must be stressed that the unburned carbon particles defined as char may constitute a substitute for natural graphite-bearing resources or be utilized for repeated combustion (Badenhorst et al. 2019a, b; Santos et al. 2019).

The structure and chemistry of graphitic carbon that can form during the graphitization process have been studied extensively in material science, because of the potential industrial applications of graphitic carbon (Yao 2015).

Graphite is obtained by the process of recrystallization/ structural organization of some forms of carbon at high pressure and high temperature. Unburned carbon from ash is a potential precursor for graphitized carbon, which has suitable structural characteristics for employment in industrial applications (European Commission 2017; Calus Moszko et al. 2017).

The aim of the research was to choose technically simple technologies of slag treatment that enable to obtain the products which could be utilized in other industrial areas, such as carbon electrode production.

\section{Materials and methods}

Figure 1 presents the research methodology. One of the byproducts of combustion-furnace slag-was used for the tests. This material was obtained in the combustion of hard coal in the pulverized coal boilers (300 and $250 \mathrm{MW}$ ) of the
Power Plant Siersza. The slag falls, due to gravity, from the combustion chamber and is discharged hydraulically through the deslagging system into settling chambers, from where it is then moved to storage areas. Samples of the slag used for testing were taken directly from the settling chambers.

The slag size composition was determined using the wet screening method as per the standard (ISO 1953:1999). Loss-on-ignition (LOI) was determined according to the procedure described in (EN 196-2:2013) at a temperature of $900{ }^{\circ} \mathrm{C}$. Size composition determinations results complete with a loss-on-ignition are presented in Table 1.

The density composition analysis was performed according to the methodology of standard (ISO 7936: 1992). From organic liquids: tribromometan, dimethylobenzene (xylene), and tetrachloroethylene, organic liquids with densities 1.4 and $1.8 \mathrm{~g} / \mathrm{cm}^{3}$ were made and used for experiments. Three products were obtained in each experiment. The products from each experiment were dried and then weighed and determined for LOI. The density composition analysis results for individual size fractions are presented in Table 3.

Magnetic separation was performed via the dry method using a neodymium magnet. Moving the magnet over the surface of the scattered particles from the studied slag sample led to the separation of fractions with magnetic and nonmagnetic characteristics. Afterwards, the separated fractions were weighed and examined for LOI values.

Separation in the rising water stream was carried out at a test stand depicted in Fig. 2. The water flow intensity was selected experimentally, so as to obtain the most optimal separation possible. The water flow intensity was within the range of $1-3 \mathrm{dm}^{3} / \mathrm{min}$.

LOI (LOI value) was used to determine the carbon content. Although LOI is a rough estimate of unburned
Fig. 1 Research methodology (*LOI-loss-on-ignition)

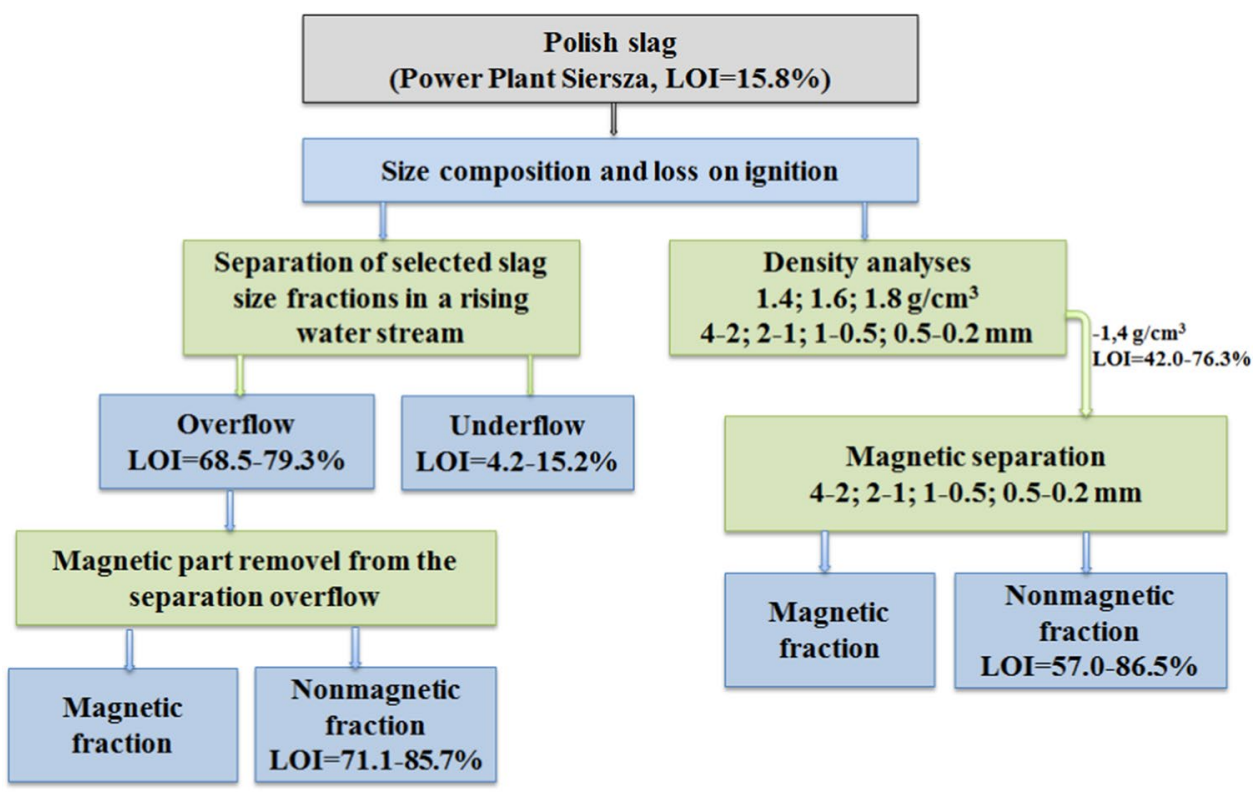


Table 1 Slag sample size composition and LOI

\begin{tabular}{lllll}
\hline Size fraction $(\mathrm{mm})$ & Yield $\gamma(\%)$ & Yield sum $(\%)$ & LOI $(\%)$ & $\begin{array}{l}\text { Unburned carbon } \\
\text { recovery mean } \\
(\%)\end{array}$ \\
\hline+4 & $20.3 \pm 0.3$ & 20.3 & $4.38 \pm 0.07$ & $4.4 \pm 0.3$ \\
$4-2$ & $10.0 \pm 0.4$ & 30.3 & $14.59 \pm 0.09$ & $7.7 \pm 0.4$ \\
$2-1$ & $9.6 \pm 0.3$ & 39.9 & $26.77 \pm 0.08$ & $12.3 \pm 0.3$ \\
$1-0.5$ & $9.6 \pm 0.4$ & 49.4 & $26.44 \pm 0.09$ & $15.1 \pm 0.4$ \\
$0.5-0.2$ & $23.2 \pm 0.4$ & 72.7 & $22.89 \pm 0.07$ & $17.6 \pm 0.4$ \\
-0.2 & $27.3 \pm 0.3$ & 100.0 & $11.00 \pm 0.08$ & $15.8 \pm 0.3$ \\
Total & 100.0 & & 15.8 & \\
\hline
\end{tabular}

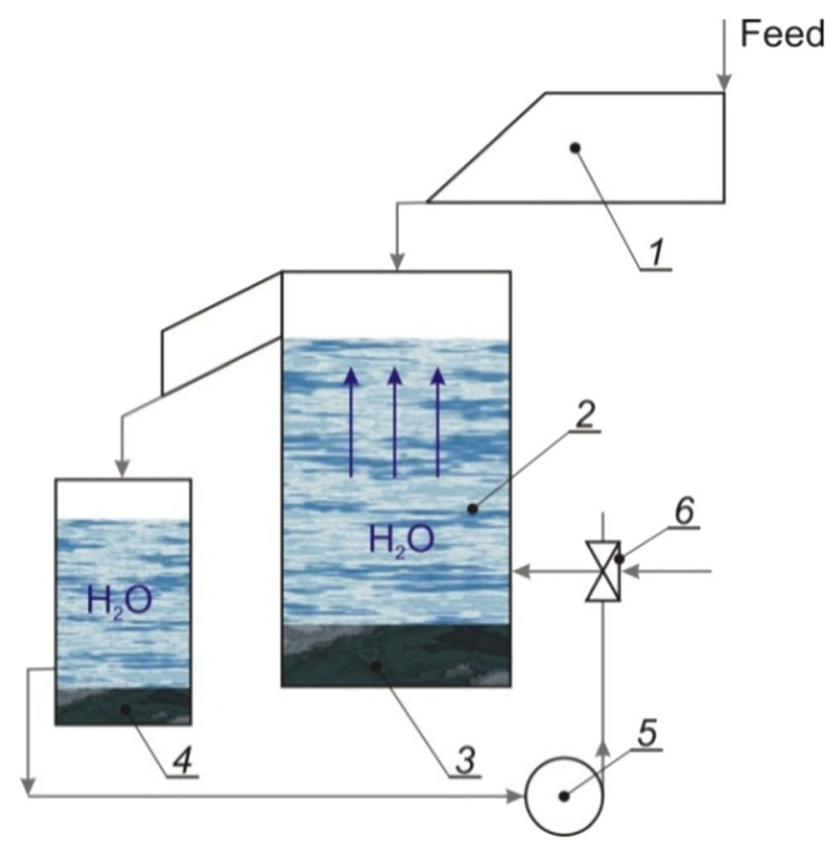

Fig. 2 Test stand diagram for separation in a rising water stream 1feeder, 2-separator, 3-sediment (bottom product), 4-overflow (top product), 5-pump, 6-three-part valve

carbon, it is a fast and simple process compared with other carbon determination techniques such as total carbon, carbon speciation, and a microscopic count (Brown and Dykstra 1995; Fan and Brown 2001; Mohebbi et al. 2015; Badenhorst et al. 2019a). Unburned carbon recovery is an indication of how much of the initial carbon mass ends up in the carbon product. Unburned carbon recovery was calculated using the following formula:

$\varepsilon=\frac{\beta}{\alpha} \times \gamma$

(ISO 1213: 1993) where $\varepsilon$-unburned carbon recovery, $\beta$ LOI value in the product; $\alpha$-LOI value in the enrichment feed; $\gamma$-product weight yield.
Sample yield is an indication of how much of the initial sample mass ends up in the carbon-rich product. Each experiment was conducted three times, and the result given is an average value.

The microscopic characterization of the selected samples was performed using a scanning electron microscope (SEM). The SEM/EDS analysis was carried out using a Hitachi SU3500 scanning microscope with variable pressure operating in cooperation with a Thermo Scientific NORAN System 7 UltraDry X-ray spectrometer with energy dispersion (EDS). The X-ray microanalysis encompassed the determination of particle size and morphology as well as an elemental composition based on particle surface observations.

\section{Results and discussion}

The slag sample size composition (Table 1) is typical for bottom slags originating from coal combustion in utility power plants (Brown and Dykstra 1995; Serre and Silcox 2000; Wilczyńska-Michalik et al. 2014; Bartoňová 2015; Anghelescu et al. 2017b). The average LOI values, constituting a measurement of unburned carbon content are $15.8 \%$ and relatively high. Unburned carbon content which is this high significantly limits the possibility of slag industrial utilization. The highest LOI, exceeding $26 \%$, occurs in $2-1 \mathrm{~mm}$ and $1-0.5 \mathrm{~mm}$ size fractions. LOI in the size fractions: $+2 \mathrm{~mm}$ and $-0.2 \mathrm{~mm}$ is smaller than in others. Due to these findings, further work was focused primarily on the aforementioned size fractions.

Figure 3 presents a photomicrograph of $1-0.5 \mathrm{~mm}$ size fraction slag particles at $30 \times$ magnification. Two kinds of particles can be clearly observed in the picture. The first kind is the dark particles with relatively regular shapes, while the second kind is much lighter particles with multiple surface irregularities. Chemical composition analysis of the micro-areas marked on selected particles exhibited significant differences in carbon, aluminium, silicon, calcium, and magnesium content. The above variation was reflected in the forecast carbon content in the analysed micro-areas. In 

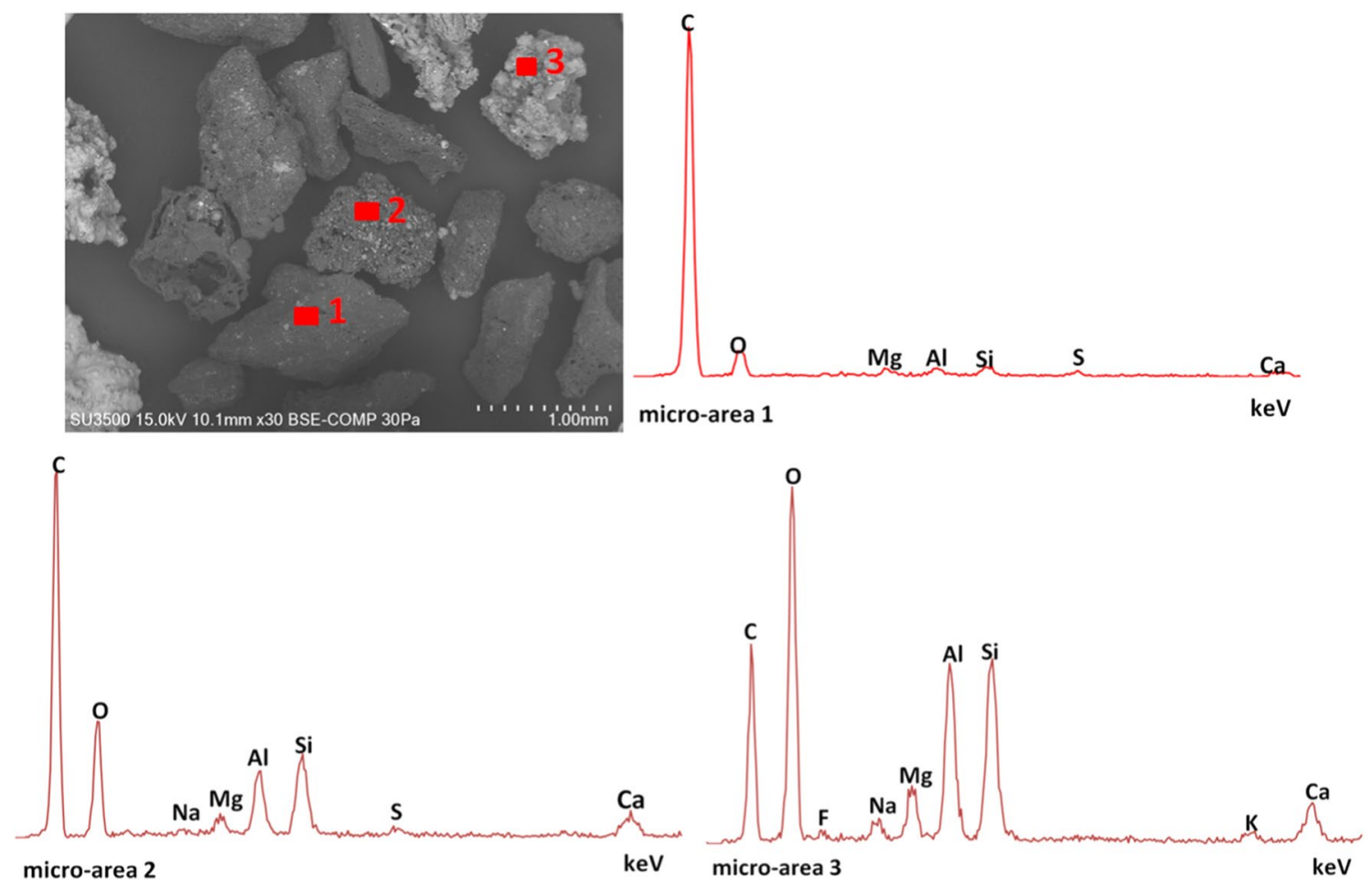

Fig. $31-0.5 \mathrm{~mm}$ size fraction slag particle photomicrograph at $\times 30$ magnification as well as elemental analysis of selected micro-areas of three different particles

terms of oxides, it amounts to approx. $91.2 \%$ for micro-area 1 and approx. $69.7 \%$ and $49.3 \%$ for areas 2 and 3, respectively. Considering the above, it can be concluded that the micro-area 1 particle contains mostly unburned carbon, the micro-area 2 particle is a partially unburned particle, while the micro-area 3 particle is a substantially burned particle.

It is widely known (Jayaranjan et al. 2014; Argiz et al. 2017) that slag typically contains relatively large amounts of iron oxides. Therefore, magnetic part separation tests were performed for three size fractions.

The tests show (Table 2) that the separation of magnetic fractions is possible for each size fraction. LOI values in the separated magnetic fractions were less than 3\%. Magnetic fraction yields ranged within $11.9-32.4 \%$ and exhibited a growing tendency following the increase in slag size reduction. LOI values in the non-magnetic fractions were 18.1-35.9\%. Unburned carbon recovery in the non-magnetic fractions was very high and exceeded $96 \%$. The above results show that slag can be enriched with unburned carbon content through the separation of non-magnetic fractions.

A photomicrograph of the magnetic fraction particles, together with the chemical analysis results of selected microareas, is presented in Fig. 4a, while the non-magnetic fraction is presented in Fig. $4 \mathrm{~b}$.

Grey-coloured particles with visible edges predominate in Fig. 4a. The analysis of micro-areas marked on three
Table 2 Magnetic separation for selected size fractions

\begin{tabular}{|c|c|c|c|c|}
\hline $\begin{array}{l}\text { Size fraction } \\
\mathrm{mm}\end{array}$ & Fraction & Yield, $\gamma(\%)$ & LOI (\%) & $\begin{array}{l}\text { Unburned } \\
\text { carbon recov- } \\
\text { ery }(\%)\end{array}$ \\
\hline \multirow[t]{2}{*}{$4-2$} & $\begin{array}{l}\text { Non-mag- } \\
\text { netic }\end{array}$ & $88.1 \pm 0.6$ & $18.1 \pm 0.7$ & $98.6 \pm 0.9$ \\
\hline & Magnetic & $11.9 \pm 0.7$ & $1.9 \pm 0.5$ & $1.4 \pm 0.8$ \\
\hline $\begin{array}{l}\text { Total, on } \\
\text { average }\end{array}$ & & 100.0 & 16.2 & 100.0 \\
\hline \multirow[t]{2}{*}{$2-1$} & $\begin{array}{l}\text { Non-mag- } \\
\text { netic }\end{array}$ & $73.5 \pm 0.6$ & $35.9 \pm 0.7$ & $98.5 \pm 0.9$ \\
\hline & Magnetic & $26.5 \pm 0.7$ & $1.5 \pm 0.4$ & $1.5 \pm 0.8$ \\
\hline $\begin{array}{l}\text { Total, on } \\
\text { average }\end{array}$ & & 100.0 & 26.8 & 100.0 \\
\hline \multirow[t]{2}{*}{$1-0.5$} & $\begin{array}{l}\text { Non-mag- } \\
\text { netic }\end{array}$ & $67.6 \pm 0.5$ & $34.2 \pm 0.7$ & $96.1 \pm 0.9$ \\
\hline & Magnetic & $32.4 \pm 0.7$ & $2.9 \pm 0.7$ & $3.9 \pm 0.8$ \\
\hline $\begin{array}{l}\text { Total, on } \\
\text { average }\end{array}$ & & 100.0 & 24.1 & 100.0 \\
\hline
\end{tabular}

particles shows the predominance of silicon, aluminium, calcium, and iron in their composition. In terms of oxides, carbon content is approx. $57.3 \%$ for micro-area 1 and approx. $30.9 \%$ and $23.0 \%$ for areas 2 and 3, respectively. The microarea 3 particle is most likely a pyrite particle, because sulphur and iron peaks are prevalent in the spectrum, while 
(a)
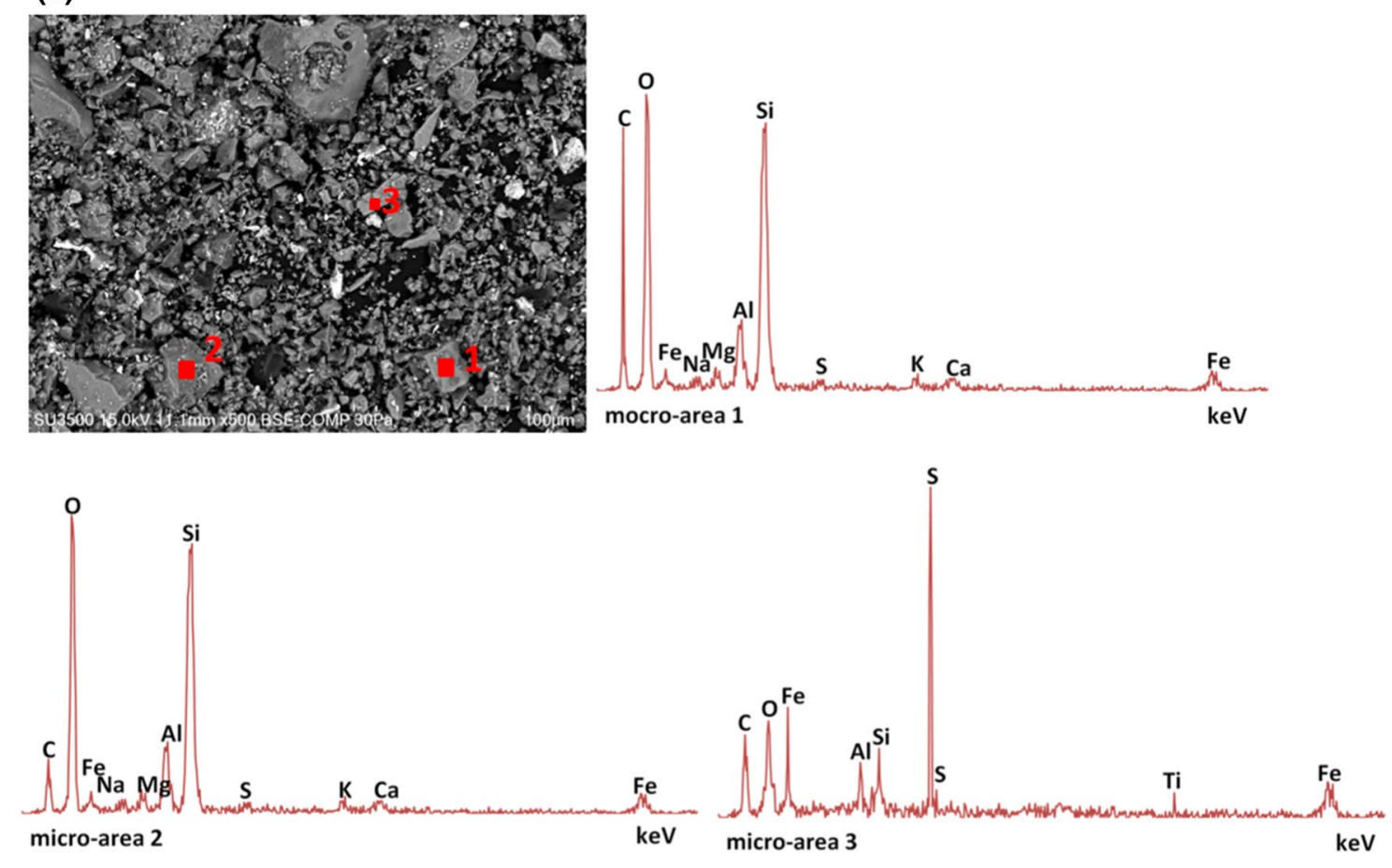

(b)
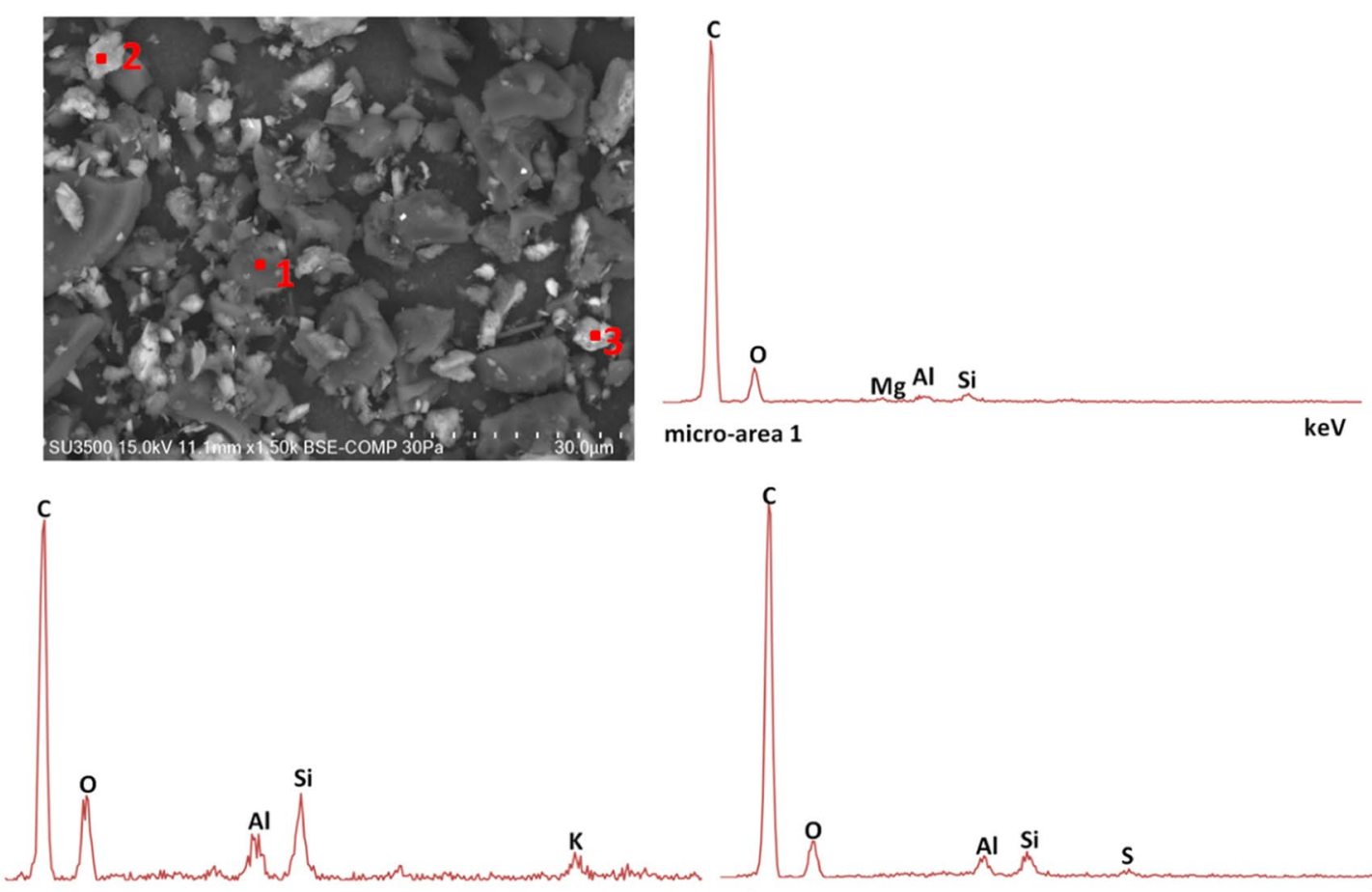

micro-area 2
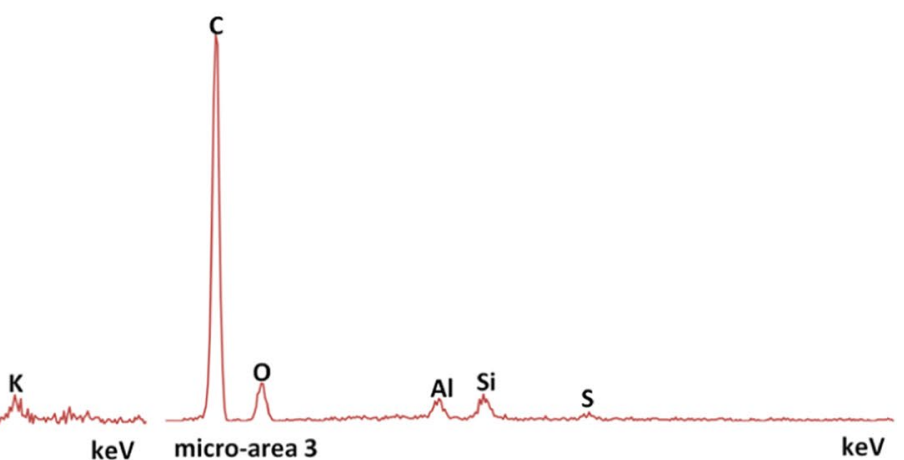

Fig. 4 Photomicrograph of $\mathbf{a}$ the magnetic fraction, $\mathbf{b}$ non-magnetic fraction separated using the magnetic separation method, at $\times 1500$ magnification as well as elemental analysis of selected micro-areas of three different particles

carbon content is less. Dark-coloured particles with round shapes predominate in Fig. 4b. The micro-area chemical composition analysis shows carbon with impurities, mostly of aluminium and silicon, to be the main component. The above is confirmed by the results of the forecast carbon content in the analysed micro-areas; carbon content was approx. 
96.5\% for micro-area 1 and approx. $78.8 \%$ and $91.0 \%$ for areas 2 and 3, respectively (in terms of oxides).

In order to determine the possibility of separating the unburned carbon particles using gravitational methods, short density analyses of slag for selected size fractions were performed. The results (Table 3) show that slag separation using gravitational methods is possible (Osborne 1988; ISO 7936: 1992; Badenhorst et al. 2019b).

The most favourable results were obtained during the separation of the $2-1 \mathrm{~mm}$ size fraction. The $-1.4 \mathrm{~g} / \mathrm{cm}^{3}$ fraction yield was $30.7 \%$, while its LOI was $76.3 \%$. The rest of the sample included: the $1.4-1.8 \mathrm{~g} / \mathrm{cm}^{3}$ fraction with $14.5 \%$ LOI and an almost clear mineral fraction with a density above $1.8 \mathrm{~g} / \mathrm{cm}^{3}$ and $0.7 \%$ LOI. Unburned carbon recovery for this size fraction was very high and amounted $89.4 \%$. A decrease in unburned carbon recovery was observed following a decrease in particle size. Lower yields of the lightest fractions and lower LOI values were obtained in the remaining size fractions.

The use of density analysis together with magnetic separation gave better results than density analysis alone (for the $-1.4 \mathrm{~g} / \mathrm{cm}^{3}$ fraction) (Table 4).

Using a magnet, 14-34\% magnetic parts with 7.3-25.3\% LOI values were separated from an individual $-1.4 \mathrm{~g} / \mathrm{cm}^{3}$ fraction size fractions. After removing the magnetic parts, the highest LOI was obtained for the $2-1 \mathrm{~mm}$ size fraction,
Table 3 Density analysis for selected size fractions

\begin{tabular}{lllll}
\hline Size fraction $(\mathrm{mm})$ & $\begin{array}{l}\text { Density fraction } \\
\mathrm{g} / \mathrm{cm}^{3}\end{array}$ & Yield, $\gamma(\%)$ & Loss-on-ignition $(\%)$ & $\begin{array}{l}\text { Unburned car- } \\
\text { bon recovery } \\
(\%)\end{array}$ \\
\hline $4-2$ & -1.4 & $22.0 \pm 0.6$ & $67.1 \pm 0.6$ & $89.4 \pm 0.9$ \\
& $1.4-1.8$ & $23.6 \pm 0.5$ & $6.6 \pm 0.7$ & $9.3 \pm 0.9$ \\
& +1.8 & $54.4 \pm 0.7$ & $0.4 \pm 0.4$ & $1.3 \pm 0.8$ \\
Total, on average & & 100.0 & 16.5 & 100.0 \\
$2-1$ & -1.4 & $30.7 \pm 0.7$ & $76.3 \pm 0.6$ & $86.4 \pm 0.9$ \\
& $1.4-1.8$ & $23.4 \pm 0.6$ & $14.5 \pm 0.7$ & $12.5 \pm 0.9$ \\
& +1.8 & $45.9 \pm 0.5$ & $0.7 \pm 0.5$ & $1.1 \pm 0.7$ \\
Total, on average & & 100.0 & 27.1 & 100.0 \\
$1-0.5$ & -1.4 & $21.6 \pm 0.6$ & $70.5 \pm 0.6$ & $37.5 \pm 0.8$ \\
& $1.4-1.8$ & $21.5 \pm 0.7$ & $46.2 \pm 0.6$ & $5.0 \pm 0.8$ \\
Total, on average & +1.8 & $56.9 \pm 0.6$ & $2.4 \pm 0.6$ & 100.0 \\
$0.5-0.2$ & & 100.0 & 26.5 & $10.1 \pm 0.9$ \\
& -1.4 & $5.2 \pm 0.7$ & $42.0 \pm 0.6$ & $31.9 \pm 0.9$ \\
& $1.4-1.8$ & $13.6 \pm 0.6$ & $50.5 \pm 0.6$ & $58.0 \pm 0.9$ \\
Total, on average & +1.8 & $81.2 \pm 0.7$ & $15.4 \pm 0.5$ & 100.0 \\
\hline
\end{tabular}

\begin{tabular}{lllll}
\hline Size fraction $(\mathrm{mm})$ & Fraction & Yield, $\gamma(\%)$ & LOI $(\%)$ & $\begin{array}{l}\text { Unburned car- } \\
\text { bon recovery } \\
(\%)\end{array}$ \\
\hline $4-2$ & & & $97.9 \pm 0.9$ \\
& Non-magnetic & $80.3 \pm 0.8$ & $81.8 \pm 0.5$ & $2.1 \pm 0.9$ \\
Total, on average & Magnetic & $19.7 \pm 0.7$ & $7.3 \pm 0.6$ & 100.0 \\
$2-1$ & Non-magnetic & $85.7 \pm 0.7$ & 67.1 & $97.2 \pm 1.0$ \\
& Magnetic & $14.3 \pm 0.7$ & $15.0 \pm 0.7$ & $2.8 \pm 1.0$ \\
Total, on average & Non-magnetic & $80.8 \pm 0.7$ & $81.3 \pm 0.6$ & 100.0 \\
$1-0.5$ & Magnetic & $19.2 \pm 0.6$ & $25.3 \pm 0.7$ & $6.9 \pm 0.9$ \\
& & 100.0 & 70.5 & 100.0 \\
Total, on average & Non-magnetic & $66.0 \pm 0.6$ & $57.0 \pm 0.7$ & $89.4 \pm 0.9$ \\
$0.5-0.2$ & Magnetic & $34.0 \pm 0.6$ & $13.1 \pm 0.7$ & $10.6 \pm 0.9$ \\
& & 100.0 & 42.1 & 100.0 \\
\hline
\end{tabular}

Table 4 Magnetic separation of $-1.4 \mathrm{~g} / \mathrm{cm}^{3}$ fractions separated using density analysis 
which was equal to $86.5 \%$. LOI for the remaining size fractions was between 57.0 and $81.8 \%$.

Figure $5 \mathrm{a}$ presents a picture of the magnetic particles separated from the $-1.4 \mathrm{~g} / \mathrm{cm}^{3}$ density fraction, while
Fig. $5 \mathrm{~b}$ presents a picture of the non-magnetic particles, together with chemical analysis results of selected particle micro-areas.

\section{(a)}
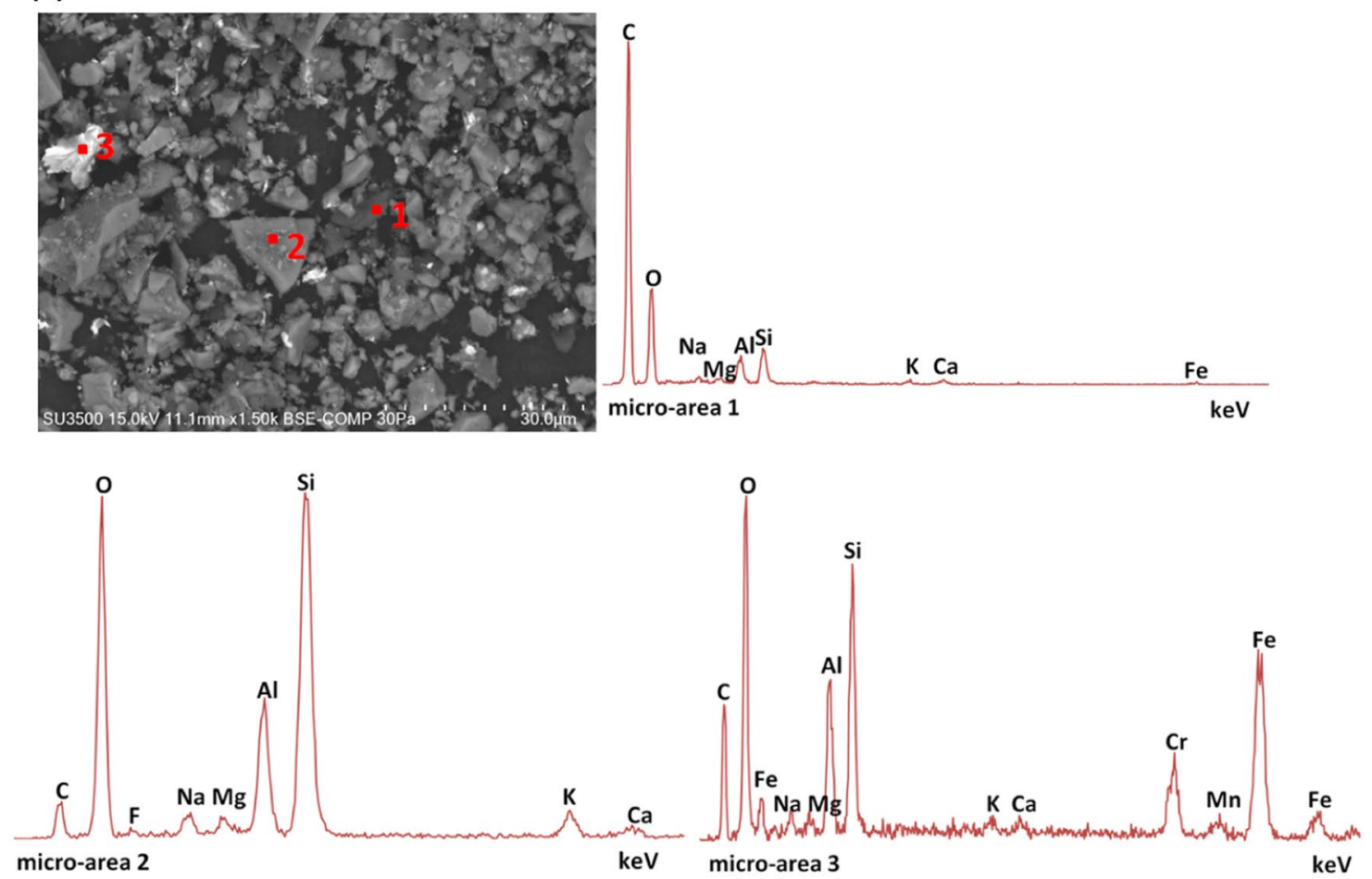

(b)
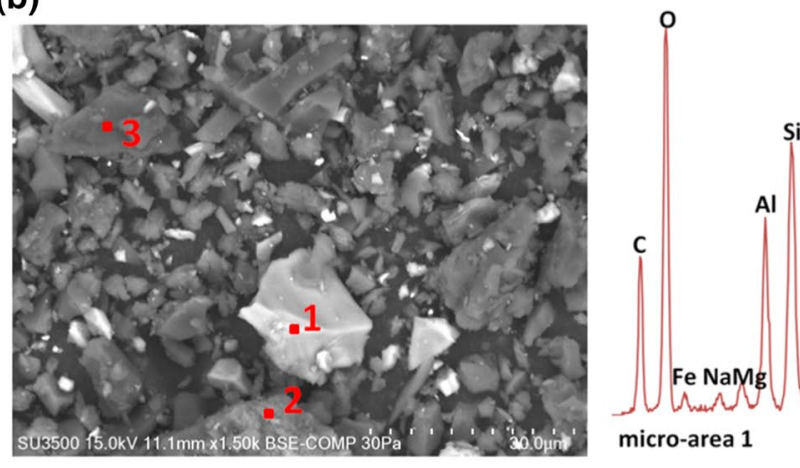

micro-area 1
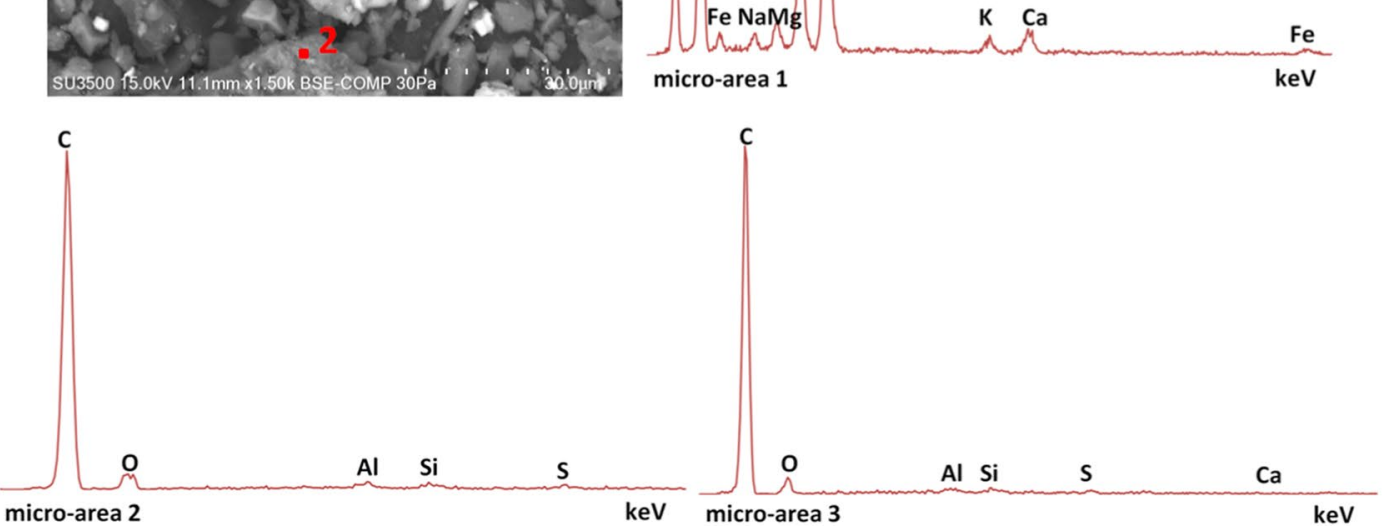

Fig. 5 Photomicrograph of a the magnetic fraction, $\mathbf{b}$ the non-magnetic fraction separated from the $-1.4 \mathrm{~g} / \mathrm{cm}^{3}$ fraction using the magnetic separation method at $\times 1500$ magnification as well as elemental analysis of selected micro-areas of three different particles 
Three micro-areas from each picture were selected for chemical composition analysis. These are the micro-areas with increasing brightness in Fig. 5a and diminishing brightness in Fig. 5b. In the micro-areas in Fig. 5a, the carbon content decreases from $83.1 \%$ (in terms of oxides) in micro-area 1 and to $19.1 \%$ and $15.7 \%$ in micro-areas 2 and 3 , respectively. In the micro-areas in Fig. 5b, the carbon content increases from 42.9 to approx. $96 \%$ for micro-areas 2 and 3 . The above is reflected in the carbon peak heights in Fig. 5a, b.

One method of fine particle gravity separation is a separation in a rising water stream. Separation of selected narrow slag size fractions using this method made it possible to separate overflow (concentrates) with $68.5-79.3 \%$ LOI values. The overflow yield was within $15.1-27.1 \%$. Underflow LOI was within 4.2-12.9\% (Table 5).

The results of separation using this method are comparable to the results obtained following the density analysis. Unburned carbon recovery in the overflow was within 77.0-55.5\% and exhibited a falling tendency following the increase in size reduction. Separation results can be controlled, to some degree, through the selection of water flow velocity in the column.

Separating magnetic parts from the overflow made it possible to increase LOI to a maximum of $85.7 \%$ for the 4-2 mm size fraction (Table 6).

For the remaining three size fractions, the LOI values after magnetic separation were within $71.1-77.5 \%$. LOI
Table 5 Separation of selected slag size fractions in a rising water stream

\begin{tabular}{lllll}
\hline Size fraction mm & Product & Yield, $\gamma(\%)$ & LOI $(\%)$ & $\begin{array}{l}\text { Unburned } \\
\text { carbon recov- } \\
\text { ery }(\%)\end{array}$ \\
\hline $4-2$ & Overflow & $15.1 \pm 0.6$ & $79.3 \pm 0.5$ & $77.0 \pm 0.8$ \\
& Underflow & $84.9 \pm 0.7$ & $4.2 \pm 0.4$ & $23.0 \pm 0.8$ \\
Total, on average & & 100.0 & 15.5 & 100.0 \\
$2-1$ & Overflow & $27.1 \pm 0.6$ & $70.1 \pm 0.5$ & $66.9 \pm 0.8$ \\
& Underflow & $72.9 \pm 0.7$ & $12.9 \pm 0.3$ & $33.1 \pm 0.8$ \\
Total, on average & & 100.0 & 28.4 & 100.0 \\
$1-0.5$ & Overflow & $21.7 \pm 0.7$ & $68.5 \pm 0.5$ & $55.5 \pm 0.9$ \\
& Underflow & $78.3 \pm 0.7$ & $15.2 \pm 0.5$ & $44.5 \pm 0.9$ \\
Total, on average & & 100.0 & 26.8 & 100.0 \\
$0.5-0.2$ & Overflow & $19.2 \pm 0.8$ & $74.5 \pm 0.4$ & $61.7 \pm 0.9$ \\
& Underflow & $80.8 \pm 0.8$ & $11.0 \pm 0.3$ & $38.3 \pm 0.9$ \\
Total on average & & 100.0 & 23.2 & 100.0 \\
\hline
\end{tabular}

Table 6 Magnetic part removal from the separation overflow

\begin{tabular}{lllll}
\hline Size fraction $(\mathrm{mm})$ & Fraction & Yield, $\gamma(\%)$ & LOI $(\%)$ & $\begin{array}{l}\text { Unburned car- } \\
\text { bon recovery } \\
(\%)\end{array}$ \\
\hline $4-2$ & Non-magnetic & $89.4 \pm 0.6$ & $85.7 \pm 0.5$ & $97.1 \pm 0.8$ \\
& Magnetic & $10.6 \pm 0.7$ & $21.8 \pm 0.4$ & $2.9 \pm 0.8$ \\
Total, on average & Non-magnetic & $86.9 \pm 0.7$ & 78.9 & 100.0 \\
$2-1$ & Magnetic & $13.1 \pm 0.7$ & $75.4 \pm 0.5$ & $93.5 \pm 0.9$ \\
& & 100.0 & $75.1 \pm 0.4$ & $6.5 \pm 0.8$ \\
Total, on average & Non-magnetic & $91.7 \pm 0.6$ & $71.1 \pm 0.6$ & 100.0 \\
$1-0.5$ & Magnetic & $8.3 \pm 0.5$ & $38.8 \pm 0.6$ & $95.3 \pm 0.9$ \\
& & 100.0 & $68.4 \pm 0.6$ & 100.0 \\
Total, on average & Non-magnetic & $88.7 \pm 0.6$ & 77.5 & $92.4 \pm 0.9$ \\
$0.5-0.2$ & Magnetic & $11.3 \pm 0.7$ & $50.2 \pm 0.5$ & $7.6 \pm 0.9$ \\
& & 100.0 & 74.4 & 100.0 \\
\hline
\end{tabular}


(a)
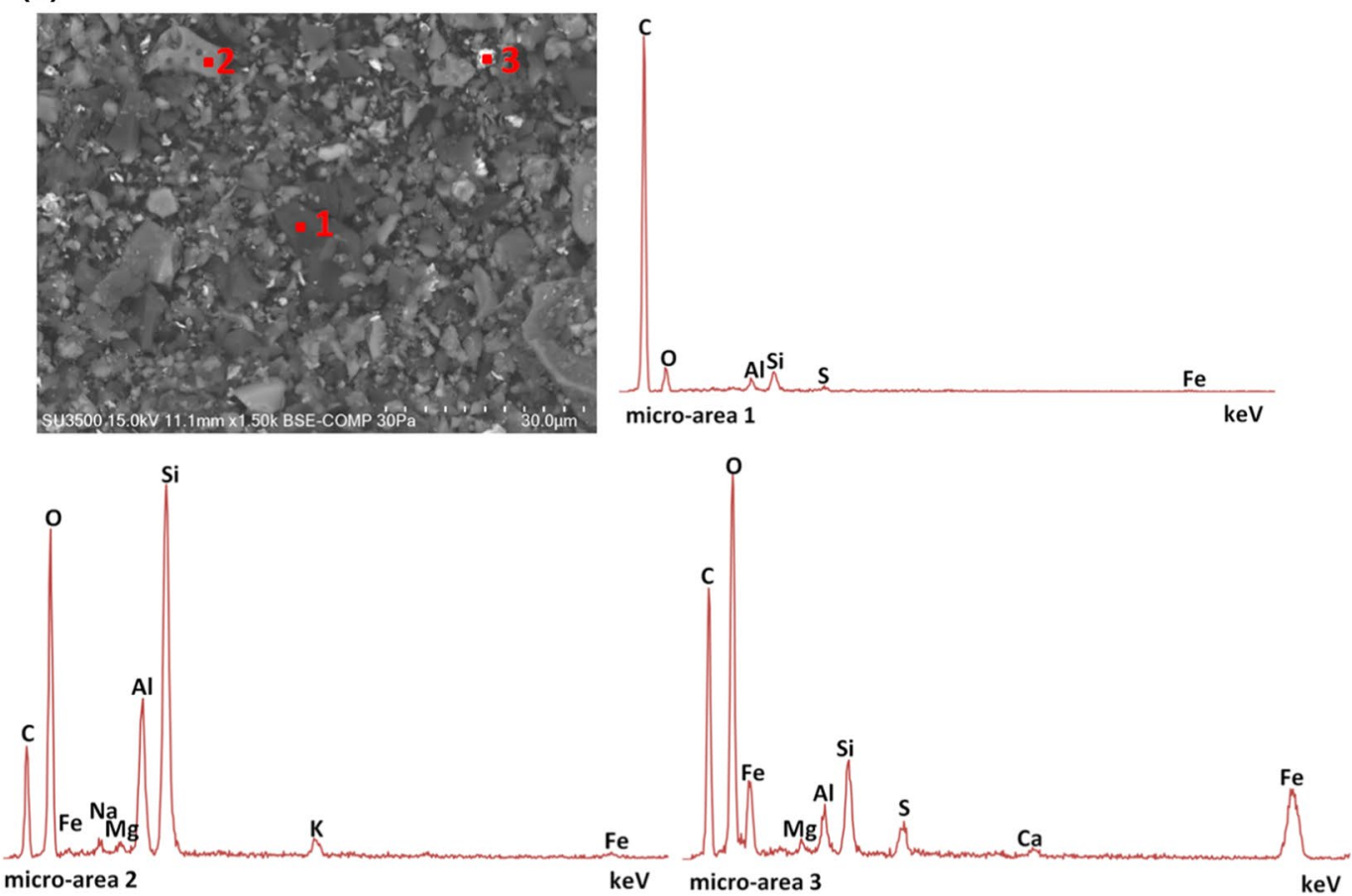

(b)
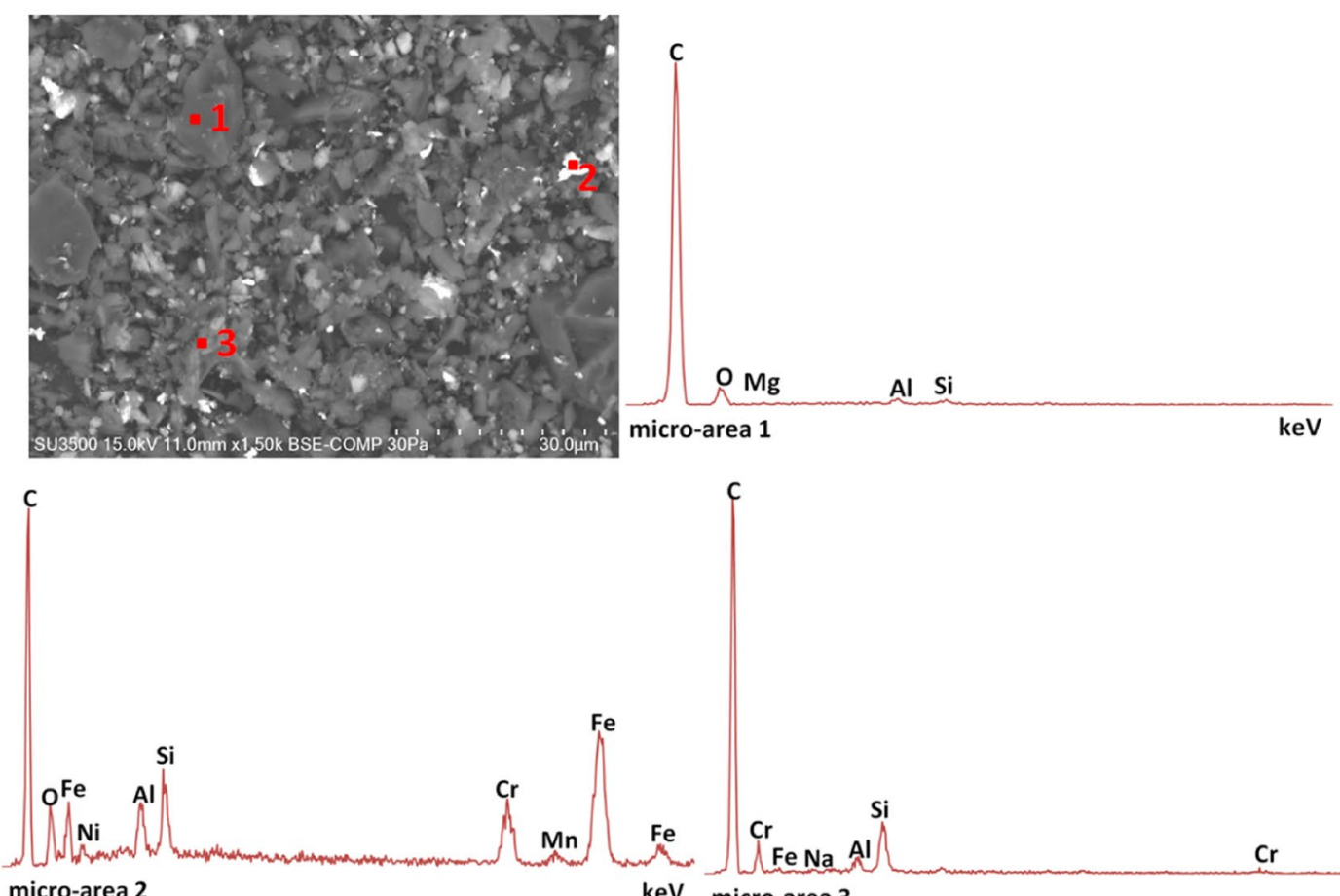

keV micro-area 3

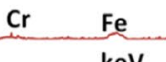

Fig. 6 Photomicrograph of $\mathbf{a}$ the magnetic fraction $\mathbf{b}$ the non-magnetic fraction separated from the overflow using the magnetic separation method at $\times 1500$ magnification as well as elemental analysis of selected micro-areas of three different particles 
of the separated magnetic fraction was within $21.8-50.2 \%$ and exhibited a growing tendency following the increasing size reduction in the particles subjected to separation. Unburned carbon recovery in the non-magnetic fractions was high and exceeded $92.4 \%$.

Figure $6 \mathrm{a}$ presents a picture of the magnetic particles separated from the overflow, while Fig. $6 \mathrm{~b}$ presents a picture of the non-magnetic particles, together with chemical analysis results of selected particle micro-area. As before, three micro-areas from each picture were selected for chemical composition analysis. Carbon content determination results for the micro-areas in Fig. 6a expressed as oxides are as follows: $90.1 \%, 35.2 \%$, and $42.3 \%$. The respective carbon contents for Fig. $6 \mathrm{~b}$ micro-areas are: $97.7 \%, 80.3 \%$, and $80.1 \%$. High carbon content is represented by the dark-coloured micro-areas in both pictures.

\section{Conclusion}

The goal of the study was to verify the possibility of separating unburned carbon from slag using magnetic and gravitational separation processes. Laboratory test results enable the formulation of the following conclusions:

The average unburned carbon content in slag, measured using LOI, is $15.8 \%$ and is too big to be utilized for industrial purposes. The results of the size composition showed that the content of unburned carbon depends on the slag grain size. The greatest unburned carbon particle content is present in $2-1 \mathrm{~mm}$ and $1-0.5 \mathrm{~mm}$ size fractions and exceeds $26 \%$. In the grain grades $+2 \mathrm{~mm}$ and less than $0.5 \mathrm{~mm}$, the content of unburned coal is smaller and is in range of $4.4-16.6 \%$.

Density analysis has shown that gravitational separation of unburned carbon particles from narrow slag size fractions is possible. LOI values of the separated $-1.4 \mathrm{~g} / \mathrm{cm}^{3}$ fractions were $42-76.3 \%$. LOI values of the separated $+1.8 \mathrm{~g} / \mathrm{cm}^{3}$ fractions were $0.4-15.4 \%$. It was found that LOI depends on the grain size. The smaller the grain, the greater the LOI.

One of the methods of gravitational separation is the separation in a rising water stream. The separation of narrow slag size fractions in a rising water stream made it possible to obtain overflow (concentrates) containing $68.5-79.3 \%$ of unburned carbon, while its yield was within $15.1-27.1 \%$. Unburned carbon recovery was $61.7-77.0 \%$.

One of the simplest methods for slags beneficiation is magnetic separation. Application of this method in various technological combinations of unburned coal separation from slags was tested. In each case, its usefulness was found. The most beneficial effects were obtained by using magnetic separation of grains enriched initially with gravitational methods. LOI concentrates above $71 \%$ were obtained in the examined cases. Unburned carbon recovery was higher than $92 \%$.

Acknowledgements This research was funded by the National Centre for Research and Development under the ERA-NET ERA-MIN Programme, Grant Number DZP/ERA-MIN-III/129/2016 "Coal char as a substituting material of natural graphite in green energy technologies" (CHARPHITE1).

Open Access This article is licensed under a Creative Commons Attribution 4.0 International License, which permits use, sharing, adaptation, distribution and reproduction in any medium or format, as long as you give appropriate credit to the original author(s) and the source, provide a link to the Creative Commons licence, and indicate if changes were made. The images or other third party material in this article are included in the article's Creative Commons licence, unless indicated otherwise in a credit line to the material. If material is not included in the article's Creative Commons licence and your intended use is not permitted by statutory regulation or exceeds the permitted use, you will need to obtain permission directly from the copyright holder. To view a copy of this licence, visit http://creativecommons.org/licenses/by/4.0/.

\section{References}

EN 196-2:2013 Methods of testing cement-part 2: chemical analysis of cement

EN 197-1: 2011 Cement-part 1: composition, specifications and conformity criteria for common cements

Anghelescu L, Abagiu T, Cruceru M, Valentim B, Diaconu B, Predeanu $G$ (2017a) Obtaining thermal insulating refractory products using ash from coal-fired thermal power plants containing residual coal. Int J Power Syst 2:14-21

Anghelescu L, Abagiu T, Cruceru M, Valentim B, Predeanu G, Diaconu B, Slavvescu V (2017b) Utilization of coal-fired ash waste in the production of heat-resistant refractory products. Int J Environ Sci 2:27-272

Argiz C, Sanjuan M, Menendez E (2017) Coal bottom ash for portland cement production. Adv Mater Sci Eng. https://doi. org/10.1155/2017/6068286

Badenhorst CJ, Wagner NJ, Valentim BRV, Viljoen KS, Santos AC, Guedes A (2019a) Separation of unburned carbon from coal conversion ash: Development and assessment of a dry method. Coal Combust Gasif Prod 11:89-96. https://doi.org/10.4177/ ccgp-d-19-00002.1

Badenhorst CJ, Wagner NJ, Valentim BRV, Santos AC, Guedes A, Białecka B, CałusMoszko J, Popescu LG, Cruceru M, Predeanu G, Viljoen KS, Lázaro-Martínez JM, Abagiu TA (2019) Char from coal ash as a possible precursor for synthetic graphite 
Recent developments of the Charphite project. In: WOCA2019 proceeding. http://www.flyash.info/AshSymposium/AshLibrary Agenda.asp\#2019 (077-abstract)

Baltrus JP, Diehl JR, Soong Y, Sands W (2002) Triboelectrostatic separation of fly ash and charge reversal. Fuel 81:757-762. https ://doi.org/10.1016/S0016-2361(01)00196-X

Ban H, Hower TX, Li JC, Schafer JL, Stencel JM (1997) Dry triboelctrostatic benefication of fly ash. Fuel 26:801-805. https://doi. org/10.1016/S0016-2361(97)00045-8

Bittner JD, Gasiorowski SA, Lewandowski W (2010) Separation technologies' 15 years of commercial experience in fly ash processing. In: XVII Konferencja Popioły z energetyki, EKOTECH Sp. z o.o., Szczecin, pp 117-131

Brown RC, Dykstra J (1995) Systematic errors in the use of loss-onignition to measure unburned carbon in fly ash. Fuel 74:570 574. https://doi.org/10.1016/0016-2361(95)98360-Q

Calus Moszko J, Bialecka B, Wierzchowski K (2017) The possibility of separing and utilizing char obtained from fly ashes. In: 17th multidisciplinary scientific geoconference SGEM 17/11, pp 1125-1132. https://doi.org/10.5593/sgem2017/11

Cheriaf M, Rocha JC, Péra J (1999) Pozzolanic properties of pulverized coal combustion bottom ash. Cem Concr Res 29:13871391. https://doi.org/10.1016/s0008-8846(99)00098-8

European Commission (2017) Communication from the Commission to the European Parliament, the Council, the European Economic and Social Committee and the Committee of the Regions on the 2017 List of Critical Raw Materials for the EU. COM (2017) 490 Final. European Commission, Brussels

Fan M, Brown RC (2001) Comparison of the loss-on-ignition and thermogravimetric analysis techniques in measuring unburned carbon in coal fly ash. Energy Fuels 15:1414-1417. https://doi. org/10.1021/ef0100496

Gray MI, Chamagne KJ, Soong Y, Killmeyer RP, Maroto-Valer MM, Andresen JM, Ciocco MV, Zandhuis PH (2002) Phisical cleaning of high carbon fly ash. Fuel Process Technol 76:11-21. https ://doi.org/10.1016/S0378-3820(02)00006-1
Groppo JA (2011) A review of coal combustion ash utilization practice In the United States. In: XVIII Konferencja Popioły z energetyki, EKOTECH Sp. z o.o., Szczecin, pp 9-25

GUS (2016) Central statistical Office. Environment. Statistical information and elaborations. Retrieved 9 February 2017 from http:// stat.gov.pl/obszarytematyczne/srodowisko-energia/srodowisko /ochrona-srodowiska-2015,1,16.html

ISO 1213:1993 Solid mineral fuels-vocabulary-part 1: terms relating to coal preparation

ISO 1953:1994 Hard coal—size analysis by sieving

ISO 7936:1992 Hard coal—determination and presentations of float and sink characteristics-General directions fir apparatus and procedures

Jayaranjan LM, Hullebusch JD, Annachhatre AP (2014) Reuse options for coal fired power plant bottom ash and fly ash. Rev Environ Sci Biotechnol. https://doi.org/10.1007/s11157-014-9336-4

Koca D, Koca H (2009) Rycycling of coal combustion wastes. Waste Manag Res 27:267-273. https://doi.org/10.1177/0734242X08 089314

Kruger RA (2010) Treatment and beneficiation of fly ash—increasing market opportunities. In: XVII Konferencja Popioły z energetyki, EKOTECH Sp. z o.o., Szczecin, pp 11-27

Mohebbi M, Rajabipour F, Scheetz BE (2015) Reliability of loss on ignition (LOI) test for determining the unburned carbon content in fly ash. Paper presented at the 2015 World of Coal Ash (WOCA), Nashville, TN, 5-7 May 2015. https://www.flyash.info

Osborne DG (1988) Coal preparation technology. Graham \& Trotman, London

Sahbaz O, Oteyaka B, Kelebek S, Ucar A, Demir U (2008) Separation of unburned carbonceus matter in bottom ash usuing Jameson cell. Sep Purif Technol 62:103-109. https://doi.org/10.1016/j. seppur.2008.01.005

Santos AC, Badenhorst Ch, Bialecka B, Calus Moszko J, Cruceru M, Guedes A, Guimaraes R, Lazaro-Martinez J (2019) Recovery of carbonaceous solid residue (char) from coal ash to use as possible substitute graphite-based materials in green energy applications. 
In: WOCA 2019 proceeding. http://www.flyash.info/AshSymposi um/AshLibraryAgenda.asp\#2019 (226-abstract)

Serre SD, Silcox GD (2000) Adsorption of elemental mercury on the residual carbon in coal fly ash. Ind Eng Chem Res 39:1723-1730. https://doi.org/10.1021/ie990680i

Soong YS, Choffstall MR, Grey ML, Knoer JP, Champagne KJ, Jones RJ, Fauth DJ (2002) Dry benefication of high loss-on-ignition fly ash. Sep Purif Technol 26:177-184. https://doi.org/10.1016/ S1383-5866(01)00162-9

Ucurum M, Toraman OY, Depci T (2011) The study on characterization of flotation to separate unburned carbon in bottomash from
Cayiran power plant. Energy Sources A Recovery Util Eff 33:562574. https://doi.org/10.1080/15567030903117638

Wilczyńska-Michalik W, Moryl R, Sobczyk J, Michalik M (2014) Composition of coal combustion by-products: the importance of combustion technology. Fuel Process Technol 124:35-43. https:// doi.org/10.1016/j.fuproc.2014.02.016

Yao ZT (2015) A comprehensive review on the applications of coal fly ash. Earth Sci Rev 141:105-121. https://doi.org/10.1016/j.earsc irev.2014.11.016 